\title{
Variation in the mode of reproduction among individuals of the ostracod Candonocypris novaezelandiae
}

\author{
J. A. CHAPLIN \\ Department of Biology, University of Wollongong, PO Box 1144, Wollongong. NSW 2500, Australia
}

\begin{abstract}
This study describes the results of laboratory breeding experiments designed to determine the mode of reproduction of female Candonocypris novaezelandiae from populations with and without males. Two morphological forms of this species were studied: a large-green and small-brown morph. Large-green females from populations without large-green males invariably generated genotypically identical daughters by parthenogenesis, regardless of the presence or absence of males in the laboratory cultures. In contrast large-green females from a population that included large-green males, when they had the opportunity for fertilization, usually produced genotypically diverse offspring of both sexes. These females were probably sexually reproducing. Unmated females from the mixed-sex population did not reproduce. The small-brown morph was collected from a single water body in which it was represented by both sexes and co-occurred with large-green parthenogenetic females. Most of the small-brown females tested reproduced sexually in the presence of males or did not reproduce in the absence of males. One small-brown unmated female, however, reproduced by parthenogenesis. Available evidence indicates that the field population of the small-brown morph includes both sexual and parthenogenetic females and that the relative abundance of the parthenogenetic females is increasing with time. The sexual and asexual forms within and between morphs are probably independent.
\end{abstract}

Keywords: allozymes, breeding trials, freshwater Ostracoda, parthenogenesis, sexual reproduction.

\section{Introduction}

Despite considerable theoretical interest in the evolution of reproductive strategies, little attention has been paid to the degree of variation shown among and especially within populations of a single species (Grosberg, 1988). This is true even of extreme cases where species may use reproductive tactics varying from outcrossed sexual reproduction to apomictic parthenogenesis (see Bell, 1982). Investigation of the exact nature and genetic consequences of the breeding system of such species is particularly important as it may help to resolve the evolutionary and ecological roles of sexual and asexual reproduction.

Some dioecious species of freshwater Ostracoda (Crustacea) are characterized by two types of local population. One type of population includes both males and females in approximately equal numbers.

Contribution number 89 from the Ecology and Genetics Group of the University of Wollongong.
The other type is apparently comprised exclusively of females. This condition has been described for 10 or so species from a range of genera (see Bauer, 1940; Hoff, 1942; McKenzie, 1971; Tetart, 1975; Bell, 1982; De Deckker, 1983; Brohnstein, 1988, Chaplin \& Ayre, 1989 ) and is generally assumed to reflect a reliance on alternative modes of reproduction. Asexual (parthenogenetic) reproduction is thought to be associated with populations without males whereas a reliance on sexual (amphimictic) reproduction is presumed for the mixed-sex populations (Hoff, 1942; McKenzie, 1971; Bell, 1982; De Deckker, 1983; Brohnstein, 1988).

Few details are known about the breeding systems of ostracod species thought to have a variable mode of reproduction. It is not known, for example, if an individual ostracod has the potential for both sexual and parthenogenetic modes of reproduction or if both sexual and parthenogenetic females may occur in the same population. Moreover, information on the breeding system of these species is usually restricted to scant 
records on the spatial and temporal distribution of males which provides only equivocal evidence of the mode of reproduction and recruitment. The presence of males in a population need not necessarily, for example, indicate a reliance on sexual reproduction: other possible interpretations of their presence are gynogenetic breeding systems (see Cable, 1971; Harshman \& Futuyma, 1985) or production of males by obligate parthenogens (see Wilson \& Woolcock, 1960; Hebert \& Crease, 1983; Stoddart, 1983a). Furthermore, the absence of males from a population may be indicative of parthenogenetic reproduction but it does not reveal the mechanism by which parthenogenesis is achieved. Identification of this mechanism is important as different types of parthenogenesis can have opposing genetic effects (e.g. the promotion of heterozygosity versus an increase in homozygosity) (White, 1973; Suomalainen et al., 1976; Bell, 1982).

Genetic evidence is essential to distinguish between apparent and realized breeding systems. There are only two published accounts of genetic evidence of ostracod species with the capacity for both sexual and parthenogenetic reproduction. One recent study has used allozymic evidence to infer that the importance of sexually generated recruitment into populations of Candonocypris novaezelandiae varies according to the presence or absence of males (Chaplin \& Ayre, 1989). More direct evidence of a potential for mixed modes of reproduction is provided by Bauer's (1940) cytological study of Heterocypris (Cyprinotus) incongruens. Bauer showed that individuals from several all-female populations produced eggs via apomictic parthenogenesis. In contrast, those from a mixed-sex population used normal meiosis. Nevertheless, studies of the mode of inheritance of genetic markers are necessary to establish beyond doubt the capacity of these species for both modes of reproduction.

C. novaezelandiae is an Australasian species of ostracod which is common in eutrophic freshwater habitats (De Deckker, 1981). This species is represented by two morphological forms: a large-green morph (the ' $C$. novaezelandiae morph' of De Deckker, 1981) and a small-brown morph (the ' $C$. assimilis morph' of De Deckker, 1981). In south-eastern Australia, many populations of this species include only females of one or sometimes both morphs (J. A. Chaplin, personal observation). The only population in this region known to comprise both sexes is one in Lake Purrumbete in southern Victoria (De Deckker, 1981). Samples recently collected from this water body have included males and females of the small-brown morph as well as females, but no males, of the largegreen morph. This suggests that the morphs rely on contrasting modes of reproduction in Lake Purrum- bete. There are populations comprising males and females of the large-green morph in other regions of Australia (De Deckker, 1981; Chaplin \& Ayre, 1989).

The primary aim of this study was to determine if, as the available evidence suggests, $C$. novaezelandiae has the capacity for both sexual and parthenogenetic reproduction. If so, then a second aim was to determine if the presence or absence of conspecific males might directly influence the mode of reproduction of females (i.e. Is this a case of facultative parthenogenesis in the absence of males?). These aims were achieved by conducting a series of laboratory breeding trials designed to determine the mode of reproduction of female $C$. novaezelandiae from

1 two populations without any males (putative asexual females)

2 a population which includes both male and females (putative sexual females); and

3 the Lake Purrumbete population which includes both a unisexual and a mixed-sex morph (putative asexual and sexual lineages respectively).

Groups of females from each population (and of each morph) were maintained in isolation, while others were kept with conspecific males. The mode of reproduction of females was assessed according to the genotypic characteristics and sex ratio of their broods, and their ability to reproduce in the absence of males.

\section{Materials and methods}

\section{Collection of specimens}

In order to test for variation in the reproductive tactics of $C$. novaezelandiae, samples were collected from the following sites which varied with respect to the presence or absence of large-green or small-brown males. 1 Two exclusively female populations of the largegreen morph in temporary ponds located near Wollongong NSW $\left(150^{\circ} 50^{\prime} \mathrm{E}, 34^{\circ} 29^{\prime} \mathrm{S}\right)$ and Robertson NSW $\left(150^{\circ} 31^{\prime} \mathrm{E}, 34^{\circ} 35^{\prime} \mathrm{S}\right)$. Both ponds are less than $40 \mathrm{~m}$ in diameter, have a maximum depth of $1 \mathrm{~m}$, and dry out during periods of low rainfall. Samples were collected from these populations in November 1988.

2 A population of large-green males and females in Cracker's Swamp in Western Australia $\left(115^{\circ} 40^{\prime} \mathrm{E}\right.$, $\left.30^{\circ} 50^{\prime} \mathrm{S}\right)$. This swamp is located some $3,500 \mathrm{~km}$ from the other sampled water bodies and is a relatively large and shallow water body (surface area $=100$ ha; maximum depth $=2 \mathrm{~m}$ ). Although a temporary water body, the swamp may hold water continuously for a number of years. Samples were collected from this site in September 1988 and January 1991.

3 A population of small-brown males and females, as 
well as large-green females in Lake Purrumbete. This is a permanent freshwater lake in southern Victoria $\left(143^{\circ} 14^{\prime} \mathrm{E}, 38^{\circ} 17^{\prime} \mathrm{S}\right)$ with a surface area of $552 \mathrm{ha}$, a maximum diameter of $3.21 \mathrm{~km}$ and a maximum depth of $45 \mathrm{~m}$ (De Deckker \& Williams, 1988). Samples were collected from the lake in February 1990.

A hand net was used to collect samples of juvenile and adult $C$. novaezelandiae from the benthos in the littoral region of these four water bodies. To ensure that ostracods collected from a single location did strictly co-occur, only a relatively small area (less than $5 \mathrm{~m}^{2}$ ) was sampled within each water body.

\section{Sorting of specimens}

The specimens collected from these water bodies were sorted to determine the sex and morphology of adults, and to select the juveniles, immature females, and males required for the breeding experiments. This sorting was done using a dissecting microscope to view the ostracods at $\times 25$ magnification. Individuals that had sufficient gonad development to allow for determination of their sex were deemed to be adults (some of these may have actually been penultimate eighth-stage instars), all others were considered to be juveniles. Females were identified by their orange ovaries which can easily be seen through the carapace (De Deckker, 1981). Similarly, the coiled testes of males were readily visible through the carapace (Chaplin \& Ayre, 1989). The morphological type of adult specimens was determined according to several carapace characteristics (mostly relative size and colour) following the description of both morphs given by De Deckker (1981).

\section{Experimental design}

In order to determine the mode of reproduction of $C$. novaezelandiae, females were either maintained in isolation or with conspecific males. Two separate series of breeding experiments were conducted: one included the small-brown and large-green morphs from Lake Purrumbete whereas the other used the large-green morph from each of Cracker's Swamp and the two temporary ponds. Both experiments were conducted under similar conditions and were of similar design, and so for the most part are described in combination.

The experiments were conducted at $15^{\circ} \mathrm{C}$ with $8: 16$ hour light:dark cycle. Selected females or male and female pairs were kept in $150 \mathrm{ml}$ plastic jars each containing $100 \mathrm{ml}$ of water and sufficient mud [bottom sediments and detritus judged to be 'ostracod-free' (see below)] to cover the bottom of the jar. The mud was provided as a food source and was occasionally replenished during the experiments. Preliminary tests showed that $C$. novaezelandiae could survive and reproduce when maintained under these conditions.

The water and mud used to maintain ostracods from the pond populations and Cracker's Swamp (1988 sample only) were judged to be 'ostracod-free' because they were collected from a water body that did not contain individuals or resting eggs of $C$. novaezelandiae (J. A. Chaplin, personal observation). The ostracods from Lake Purrumbete were maintained with mud and water collected from the site at which these ostracods were collected. However, prior to being placed in the jar, the mud was treated to kill any specimens or resting stages of $C$. novaezelandiae that it might contain. This treatment consisted of mixing the mud with a little water, then freezing the mixture, and finally boiling it in a microwave. Since all of the isolated females from the 1988 Cracker's Swamp sample died prematurely, this part of the experiment was repeated using females collected in 1991 (Table 1). These latter females were maintained on swamp mud which was treated in a similar fashion to the mud from Lake Purrumbete.

Ten control jars were set up for each experiment to test for the possibility that specimens of $C$. novaezelandiae 'hidden' in the mud and water had been accidentally introduced into the culture jars. Only mud and water were placed in these control jars. The contents of the control jars were examined on several occasions but no C. novaezelandiae were found. It was therefore assumed that any specimens observed in the experimental jars were either the individuals that had deliberately been introduced into them or the offspring of these individuals.

Females placed in isolation. Groups of between 13 and 7 females per population were kept alone in separate culture jars in order to assess their capacity to reproduce by parthenogenesis (Table 1). Where possible, females were isolated as juveniles (Table 1). As ostracods do not usually copulate until the adult stage (Pennack, 1953), this was thought to ensure that they had not been fertilized prior to isolation.

Some of the females from the pond populations were placed in isolation as mature adults (Table 1). These pond females were from populations which apparently do not include males (J. A. Chaplin personal observation), and so were unlikely to have been fertilized prior to isolation.

More than 90 per cent of adult individuals from Lake Purrumbete were of the small-brown morph. The probability of a randomly selected juvenile being of the large-green morph was therefore presumably small. So, to ensure that large-green females from Lake Purrumbete were included in this part of the experiment, 10 such females were maintained in isolation from an 


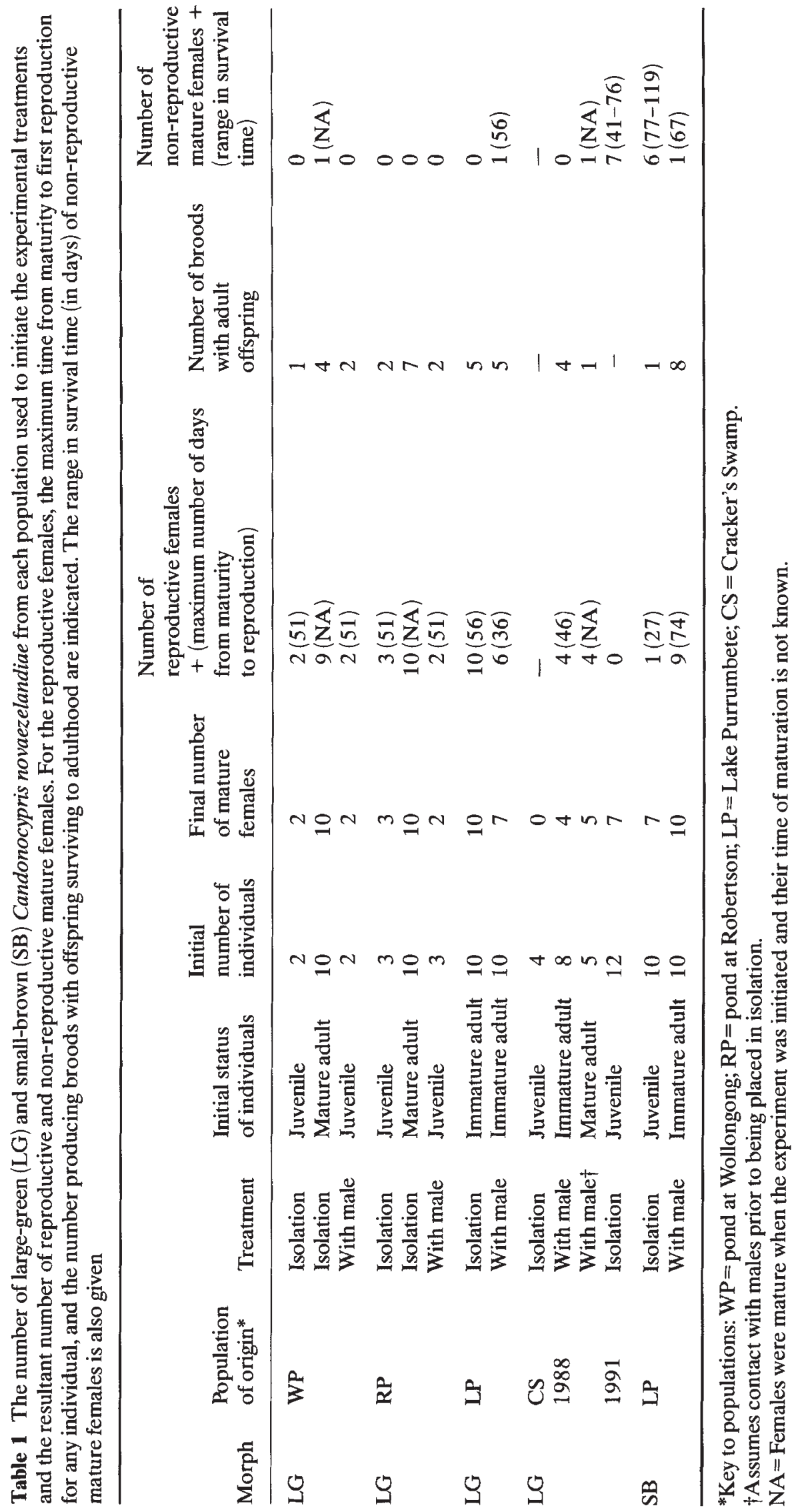


immature adult stage (at this stage their morphological form could be recognized) (Table 1). These females had been exposed to small-brown males in Lake Purrumbete and may or may not have been fertilized prior to isolation.

Females placed with males. Groups of between 2 and 10 females per population were maintained together with potential mates (Table 1). This was done as a test of their capacity to use sexual reproduction. All females from Lake Purrumbete were placed with small-brown males while those from the swamp and pond populations were placed with large-green ones.

Females from Cracker's Swamp and Lake Purrumbete were immature adults when intially placed with males (Table 1), but presumably they had had earlier exposure to males in their population of origin. In an attempt to mimic these conditions, laboratory-bred juveniles of pond stock were placed with males shortly after they hatched.

Finally, five mature females from Cracker's Swamp were placed in isolation. These females presumably had had some opportunity to mate in the mixed-sex population from which they had been recently collected (Table 1).

\section{Monitoring of experiments}

Culture jars were checked every 2-3 weeks to monitor the survival and reproductive status of the female $C$. novaezelandiae. Not all of the females that were introduced into culture jars survived to reach maturity and only some of the survivors were reproductive (Table 1). Reproduction was judged to have occurred if juvenile $C$. novaezelandiae were observed in the jar. All reproductive females produced offspring within 56 days (large-green morph) or 74 days (small-brown morph) of reaching maturity (Table 1). Females that had reproduced (and their male partners) were frozen at $-80^{\circ} \mathrm{C}$ for later electrophoretic analysis. Their offspring were maintained in the culture jars until they were mature enough for their sex to be determined and then also frozen pending electrophoretic comparison with their parent(s). Not all reproductive females produced offspring that reached adulthood (Table 1). Such females were not included in any analyses since, without information on the sex ratio and genotypes of their offspring, their mode of reproduction could not be confirmed.

\section{Electrophoresis}

Horizontal starch-gel ( 12 per cent w/v) electrophoresis was used to infer the genotypes of each of the surviving females, their male partners (if applicable) and all of their surviving adult offspring for up to four enzymeencoding loci. The enzymes assayed were glucose phosphate isomerase (GPI, EC: 5.3.9.1); phosphoglucomutase (PGM, EC: 2.7.5.1); mannose phosphate isomerase (MPI, EC: 5.3 .1 .8 ) and arginine phosphokinase (APK, EC: 2.7.3.3). These enzymes were chosen because surveys of allozymic variation in $C$. novaezelandiae have revealed each of these to be polymorphic in at least some populations. The scored polymorphism of APK was detected in the middle zone of three zones of activity. All assays were conducted using a tris-citrate buffer with a $\mathrm{pH}$ of 8 . Details of electrophoretic procedures and buffer recipes are given in Chaplin \& Ayre (1989).

For each polymorphism, inferred heterozygotes and homozygotes were readily distinguished and the quaternary structure of enzymes was judged to correspond to that described by Richardson et al. (1986). Alleles were labelled alphabetically in order of the decreasing electrophoretic mobility of their enzyme products.

Previous assays on the large-green morph from Cracker's Swamp have revealed numerous females that and heterozygous at the Pgm locus (as indicated by their two-banded phenotype) but only single-banded males (J. A. Chaplin, personal observation). Hence, it appears that this locus is sex-linked and is represented by a single gene in the heterogamous male sex. The Pgm genotypes of males were inferred accordingly.

\section{Assessment of the mode of reproduction}

The mode of reproduction used by females was assessed by: (a) comparing their multi-locus genotypes to those of their offspring, so as to determine the mode of inheritance at marker loci; (b) ascertaining the sex ratio of their broods; and (c) in some cases determining their ability to reproduce without males.

The exclusive production of genotypically identical daughters was considered to be indicative of asexual (parthenogenetic) reproduction, especially when the female parent was heterozygous for at least one locus. In such cases, the probability of genotypic identity between a heterozygous sexually reproducing female and all of her progeny decreases markedly with increasing brood size and was calculated as the product of single locus probabilities where $P=0.5^{m}$, where $n$ is the number of heterozygous progeny at the $i$ th locus (Stoddart, 1983b). In contrast, genotypically diverse broods that included both males and females were judged to have been generated by sexual reproduction. 


\section{Results}

\section{Parthenogenetic reproduction}

Large-green morph. Large-green female $C$. novaezelandiae from populations without large-green males (i.e. from the two pond populations and Lake Purrumbete) invariably reproduced by parthenogenesis. Twenty-eight females from these populations, representing a total of nine different multi-locus genotypes (clones), were shown to use this mode of reproduction (Tables 2 and 3 ). The progeny of these females, with but one exception (discussed below), consisted of sets of genotypically uniform daughters. Collectively they produced 292 daughters and no sons (Table 2 and 3 ). Genotypically uniform broods were produced by at least one heterozygous female per population sampled and a total of 16 such females: a finding which showed that Mendelian segregation had not occurred and provides convincing evidence of asexual reproduction. Indeed, the probability of obtaining this outcome for heterozygous sexually reproducing individuals is vanishingly small (Tables 2 and 3 ).

The presence or absence of males in the laboratory cultures had no apparent effect on the parthenogenetic mode of reproduction of these females. Of the 28 parthenogenetic females, 19 were isolated virgin females. The remaining nine were made up of five from
Lake Purrumbete that had been kept with small-brown males and four pond females that had been partnered with large-green males (Tables 2 and 3). Usually the males involved survived at least until the offspring had hatched but those of two pond females did not (Table 3 , crosses 2 and 4). In these cases, it was impossible to determine if the males died before mating could take place. Any paternal input of genes into the progeny of females partnered with males, if it had occurred, would have been easily detected as each surviving male possessed some alleles that were not present in the female parent (e.g. the 'b' or 'e' allele at the Mpi locus) (Table 3).

One large-green female from Lake Purrumbete was exceptional in that she produced a diverse brood of three daughters. Two of these inherited her four-locus genotype and were 'ac' heterozygotes at both the Pgm and $M p i$ loci. The third daughter, while identical to the others for three loci, was a 'cc' homozygote at the Pgm locus (Table 3, cross 7). The female parent was partnered with a small-brown male but, as he was a ' $b$ ' hemizygote for the Pgm locus, the different allele was not paternally derived. Indeed, given that the brood in question included only females and that variation was restricted to one allele in only one of the progeny, it was probably generated asexually. The most likely source of the variation is either a point mutation or recombination during parthenogenetic egg formation.

Table 2 The multi-locus genotypes (where known) and population of origin of 19 large-green (LG) and one small-brown (SB) female Candonocypris novaezelandiae that reproduced in the absence of males, and the number and genotypes of their allfemale offspring. $P$ is the maximum probability of sexual production of the observed number of genotypically identical offspring and is based on the expectation that sexual reproduction would involve Mendelian segregation at heterozygous loci in the female parent

\begin{tabular}{|c|c|c|c|c|c|c|c|c|c|c|c|c|c|}
\hline \multirow[b]{3}{*}{ Morph } & \multirow{3}{*}{$\begin{array}{l}\text { Population } \\
\text { of origin* }\end{array}$} & \multirow{3}{*}{$\begin{array}{l}\text { Genotype } \\
\text { number }\end{array}$} & \multirow{3}{*}{$\begin{array}{l}\text { Number } \\
\text { of female } \\
\text { parents }\end{array}$} & \multicolumn{4}{|c|}{ Genotype of parent } & \multicolumn{4}{|c|}{ Genotypes of offspring } & \multirow{3}{*}{$\begin{array}{l}\text { Number of } \\
\text { offspring } \\
\text { produced } \\
\text { (all females) }\end{array}$} & \multirow[b]{3}{*}{$P$} \\
\hline & & & & \multicolumn{4}{|c|}{ Enzyme locus } & \multicolumn{4}{|c|}{ Enzyme locus } & & \\
\hline & & & & $G p i$ & Apk & $P g m$ & $M p i$ & $G p i$ & Apk & Pgm & $M p i$ & & \\
\hline LG & WP & 1 & 2 & - & $b c$ & $b b$ & $c c$ & - & $b c$ & $b b$ & $c c$ & $15+13=28$ & $3.7 \times 10^{-9}$ \\
\hline LG & WP & 2 & 2 & - & $a c$ & $b d$ & $c g$ & - & $a c$ & $b d$ & $c g$ & $19+15=34$ & $2.0 \times 10^{-31}$ \\
\hline LG & WP & 3 & 1 & - & $b c$ & $b d$ & $c g$ & - & $b c$ & $b d$ & $c g$ & 2 & $1.6 \times 10^{-2}$ \\
\hline LG & $\mathrm{RP}$ & 4 & 6 & - & $b b$ & $b d$ & $f g$ & - & $b b$ & $b d$ & $f g$ & $\begin{array}{l}19+15+14+13+ \\
12+9=82\end{array}$ & $4.3 \times 10^{-50}$ \\
\hline LG & RP & 4 & 3 & & Not d & determi & ined & - & $b b$ & $b d$ & $f g$ & $15+14+3=32$ & $5.4 \times 10^{-20} t$ \\
\hline LG & LP & 5 & 3 & $b b$ & $b b$ & $d d$ & $g g$ & $b b$ & $b b$ & $d d$ & $g g$ & $10+7+2=19$ & NA \\
\hline LG & LP & 6 & 1 & & Not $\mathrm{c}$ & determi & ined & $b b$ & $b b$ & $b d$ & $g g$ & 11 & $4.9 \times 10^{-4} \dagger$ \\
\hline LG & LP & 7 & 1 & & Not c & determi & ined & $d d$ & $e e$ & $c c$ & $a a$ & 13 & NA \\
\hline SB & LP & 8 & 1 & $b b$ & - & $a c$ & $c c$ & $b b$ & - & $a c$ & $c c$ & 5 & $3.1 \times 10^{-2}$ \\
\hline
\end{tabular}

*Key to populations: $\mathrm{WP}=$ pond at Wollongong; $\mathrm{RP}=$ pond at Robertson; $\mathrm{LP}=\mathrm{Lake}$ Purrumbete.

$\dagger$ Assumes no prior contact with males.

$\mathrm{NA}=$ No heterozygous loci were detected in the female parent. 
Table 3 The multi-locus genotypes (where known) and population of origin of nine large-green female Candonocypris novaezelandiae that were partnered with males, the morph and genotypes of their male partners (where known), and the number and genotypes of their all-female offspring. $P$ is the maximum probability of sexual production of the observed number of genotypically identical offspring and is based on the expectation that sexual reproduction would involve Mendelian segregation at heterozygous loci in the female parent

\begin{tabular}{|c|c|c|c|c|c|c|c|c|c|c|c|c|c|c|c|c|c|}
\hline \multirow[b]{2}{*}{$\begin{array}{l}\text { Population } \\
\text { of origin* }\end{array}$} & \multirow[b]{2}{*}{$\begin{array}{l}\text { Cross } \\
\text { number }\end{array}$} & \multirow[b]{2}{*}{$\begin{array}{l}\text { Morph } \\
\text { of male } \dagger\end{array}$} & \multicolumn{4}{|c|}{$\begin{array}{l}\text { Genotype of } \\
\text { male partner }\end{array}$} & \multicolumn{5}{|c|}{$\begin{array}{l}\text { Genotype of } \\
\text { female parent }\end{array}$} & \multicolumn{4}{|c|}{$\begin{array}{l}\text { Genotypes of } \\
\text { offspring }\end{array}$} & \multirow{2}{*}{$\begin{array}{l}\text { Number of } \\
\text { offspring } \\
\text { (all females) }\end{array}$} & \multirow[b]{2}{*}{$P$} \\
\hline & & & \multicolumn{3}{|c|}{$\begin{array}{l}\text { Enzyme locus } \\
\text { Gpi Apk Pgm }\end{array}$} & $M p i$ & & \multicolumn{2}{|c|}{ Enzyme locus } & $\begin{array}{l}\text { cus } \\
\text { Pgm }\end{array}$ & $M p i$ & \multicolumn{2}{|c|}{ Enzyme locus } & Pgm & $M p i$ & & \\
\hline WP & 1 & LG & - & $c c$ & $c$ & $b b$ & $x$ & - & $b b$ & $b d$ & $c g$ & - & $b b$ & $b d$ & $c g$ & 11 & $2.0 \times 10^{-7}$ \\
\hline WP & 2 & LG & Not $c$ & deterr & mined $\neq$ & & $x$ & - & $a c$ & $b d$ & $c g$ & - & $a c$ & $b d$ & - & 13 & $1.5 \times 10^{-8}$ \\
\hline $\mathrm{RP}$ & 3 & LG & - & $c c$ & $e$ & $b b$ & $x$ & - & $b b$ & $b d$ & $f g$ & - & $b b$ & $b d$ & - & 9 & $2.0 \times 10^{-3}$ \\
\hline RP & 4 & LG & Not $\mathrm{c}$ & deterr & mined§ & & $x$ & - & $b b$ & $b d$ & $f g$ & - & $b b$ & $b d$ & $f g$ & 5 & $9.8 \times 10^{-4}$ \\
\hline LP & 5 & SB & $b b$ & $b b$ & $b$ & $e e$ & $x$ & $b b$ & $b b$ & $b d$ & $g g$ & $b b$ & $b b$ & $b d$ & $g g$ & 11 & $4.9 \times 10^{-4}$ \\
\hline LP & 6 & SB & $b b$ & $b b$ & $a$ & $e e$ & $x$ & $b b$ & $b b$ & $d d$ & $g g$ & $b b$ & $b b$ & $d d$ & $g g$ & 9 & NA \\
\hline LP & 7 & SB & $b d$ & $b b$ & $b$ & $e e$ & $x$ & $d d$ & $e e$ & $a c$ & $a c$ & $d d$ & $e e$ & $a c$ & $a c$ & 2 & NA \\
\hline & & & & & & & & & & & & $d d$ & $e e$ & $c c$ & $a c$ & 1 & \\
\hline LP & 8 & SB & $d d$ & $b b$ & $b$ & $e e$ & $x$ & Not & detern & nined & & $b b$ & $b b$ & $d d$ & $g g$ & 7 & NA \\
\hline LP & 9 & SB & $d f$ & $b b$ & $b$ & $e e$ & $x$ & Not & detern & nined & & $b b$ & $b b$ & $d d$ & $g g$ & 3 & NA \\
\hline
\end{tabular}

${ }^{*}$ Key to populations: $\mathrm{WP}=$ pond at Wollongong; $\mathrm{RP}=$ pond at Robertson; $\mathrm{LP}=$ Lake $\mathrm{Purrumbete}$.

$\dagger \mathrm{LG}=$ large-green morph; $\mathrm{SB}=$ small-brown morph.

$\ddagger$ Male survived in vitro for between 47 and 92 days,

\$Male survived in vitro for less than 47 days.

$\mathrm{NA}=$ No heterozygous loci were detected in the female parent or not all offspring had identical genotypes.

In contrast to large-green females from the populations without large-green males, those from the mixedsex population (Cracker's Swamp) did not reproduce without fertilization. Seven mature virgin females from this population survived in isolation for between 41 and 125 days and none were reproductive (Table 1 ).

Small-brown morph. One small-brown female was shown to reproduce by parthenogenesis. This was the only female of this morph that reproduced when maintained in isolation. Like her large-green counterparts, she produced only daughters all of which inherited the maternal genotype (including heterozygosity at the Pgm locus) (Table 2). Six other mature small-brown females were maintained in isolation for a relatively long period of time (between 77 and 119 days) but did not reproduce (Table 1). This suggests that these females did not have the capacity for parthenogenesis.

One of the non-reproductive isolated females was subsequently shown to reproduce sexually after she spent a period of time with two small-brown males. The males were introduced into her culture jar after she had spent 79 days in isolation in a mature state, and within 43 days of this happening she sexually produced offspring (Table 4, cross 7). Only one of the remaining isolated females survived throughout this period but none were reproductive.

\section{Sexual reproduction}

Large-green morph. Five large-green females from the mixed-sex population (Cracker's Swamp) were reproductive and all of these probably used sexual reproduction. Three of the five produced genotypically diverse progeny and all five had at least one male offspring (Table 4). All of these females had had contact with conspecific males. Four of them had been maintained in vitro with males and the fifth one was a mature adult when she was placed in isolation. Presumably then, either stored sperm or fertilized eggs were carried with her into the jar.

Two of the swamp females were heterozygous for one locus and the range of genotypes displayed by their respective offspring suggests that Mendelian segregation had occurred (Table 4, crosses 1 and 5). Furthermore, an offspring of one of these females possessed an allele that was not of maternal origin (Table 4, cross 5 , the 'c' allele at the Gpi locus). This allele may have been of paternal origin but this could not be confirmed as the mate(s) of this female was not known. However, 
Table 4 The genotypes of five large-green (LG) female Candonocypris novaezelandiae from Cracker's Swamp (CS) and nine small-brown $(\mathrm{SB})$ females from Lake Purrumbete $(\mathrm{LP})$ that were partnered with large-green and small-brown males respectively, the genotypes of their male partners (where known), and the number, sex and genotypes of their offspring. The expected frequency of offspring genotypes is that expected to result from a sexual cross between the male and females pair. Males were inferred to be hemizygous for the Pgm locus

\begin{tabular}{|c|c|c|c|c|c|c|c|c|c|c|c|c|}
\hline \multirow[b]{2}{*}{$\begin{array}{l}\text { Population } \\
\text { of origin }\end{array}$} & \multirow[b]{2}{*}{ Morph } & \multirow[b]{2}{*}{$\begin{array}{l}\text { Cross } \\
\text { number }\end{array}$} & \multicolumn{3}{|c|}{$\begin{array}{l}\text { Genotype of } \\
\text { male partner }\end{array}$} & \multicolumn{2}{|c|}{$\begin{array}{l}\text { Genotype of } \\
\text { female parent }\end{array}$} & \multicolumn{4}{|c|}{$\begin{array}{l}\text { Observed and expected } \\
\text { offspring genotypes }\end{array}$} & \multirow{2}{*}{$\begin{array}{l}\text { Number of } \\
\text { male:female } \\
\text { offspring }\end{array}$} \\
\hline & & & $\begin{array}{l}\text { Locus } \\
G p i\end{array}$ & Pgm & & $\begin{array}{l}\text { Locus } \\
G p i\end{array}$ & Pgm & $\begin{array}{l}\text { Locus } \\
G p i\end{array}$ & Pgm & Obs. & Exp. & \\
\hline \multirow[t]{3}{*}{ CS } & LG & 1 & $b b$ & $e$ & $x$ & $a b$ & $e e$ & $b b$ & $e$ & $4 \mathrm{~m}$ & $3 \mathrm{~m}$ & $6: 3$ \\
\hline & & & & & & & & $a b$ & $e$ & $2 m$ & $3 \mathrm{~m}$ & \\
\hline & & & & & & & & $b b$ & $e e$ & $2 \mathrm{f}$ & $1.5 \mathrm{f}$ & \\
\hline \multirow{2}{*}{ CS } & LG & 2 & & & $x$ & & & $a b$ & $e e$ & $1 \mathrm{f}$ & $1.5 \mathrm{f}$ & \\
\hline & & 2 & $b b$ & $e$ & & $b b$ & $c c$ & $\begin{array}{l}b b \\
b b\end{array}$ & $\begin{array}{l}c \\
c e\end{array}$ & $\begin{array}{l}1 \mathrm{~m} \\
2 \mathrm{f}\end{array}$ & $\begin{array}{l}1 \mathrm{~m} \\
2 \mathrm{f}\end{array}$ & $1: 2$ \\
\hline \multirow[t]{2}{*}{ CS } & LG & $3^{*}$ & $b b$ & $c$ & $x$ & $b b$ & $c c$ & $b b$ & $c$ & $1 \mathrm{~m}$ & NA & $1: 0$ \\
\hline & & & $b b$ & $e$ & & & & & & & & \\
\hline \multirow[t]{3}{*}{ CS } & LG & 4 & $b b$ & $e$ & $x$ & $b b$ & $e e$ & $b b$ & $e$ & $2 m$ & $3 \mathrm{~m}$ & $3: 2$ \\
\hline & & & & & & & & ND & ND & $1 \mathrm{~m}$ & - & \\
\hline & & & & & & & & $b b$ & $e e$ & $2 \mathrm{f}$ & $2 \mathrm{f}$ & \\
\hline \multirow[t]{5}{*}{ CS } & LG & $5 \dagger$ & - & - & $x$ & $b b$ & $c e$ & $b b$ & $c$ & $2 \mathrm{~m}$ & NA & $6: 6$ \\
\hline & & & & & & & & $b b$ & $e$ & $2 \mathrm{~m}$ & NA & \\
\hline & & & & & & & & ND & ND & $2 \mathrm{~m}$ & NA & \\
\hline & & & & & & & & $b c$ & - & 1f & NA & \\
\hline & & & & & & & & $b b$ & $c e$ & $4 f$ & NA & \\
\hline \multirow{5}{*}{ LP } & SB & 6 & be & & & & & $b b$ & $c c$ & 1f & NA & \\
\hline & & 6 & $b e$ & $a$ & $x$ & $e f$ & $a b$ & $e e$ & $b$ & $1 \mathrm{~m}$ & $<1 \mathrm{~m}$ & $1: 7$ \\
\hline & & & & & & & & $\begin{array}{l}e e \\
e f\end{array}$ & $\begin{array}{l}a b \\
a b\end{array}$ & $\begin{array}{l}2 \mathrm{f} \\
2 \mathrm{f}\end{array}$ & $\begin{array}{l}<1 \mathrm{f} \\
<1 \mathrm{f}\end{array}$ & \\
\hline & & & & & & & & $e f$ & $\begin{array}{l}a b \\
a a\end{array}$ & $2 f$ & $<1 \mathrm{f}$ & \\
\hline & & & & & & & & $e e$ & $a a$ & 1f & $<1 \mathrm{f}$ & \\
\hline \multirow{6}{*}{ LP } & SB & $7 \ddagger$ & be & $b$ & $x$ & $b f$ & $b b$ & be & $b$ & $3 m$ & NA & $7: 4$ \\
\hline & & & $e f$ & $b$ & & & & $b f$ & $b$ & $1 \mathrm{~m}$ & NA & \\
\hline & & & & & & & & $e f$ & $b$ & $1 \mathrm{~m}$ & NA & \\
\hline & & & & & & & & $f f$ & $b$ & $2 m$ & NA & \\
\hline & & & & & & & & be & $b b$ & $2 \mathrm{f}$ & NA & \\
\hline & & & & & & & & $b f$ & $b b$ & $1 \mathrm{f}$ & NA & \\
\hline \multirow{6}{*}{ LP } & SB & 8 & $b b$ & $a$ & $x$ & $b b$ & $a b$ & $f f$ & $b b$ & 1f & NA & \\
\hline & & & & & & & $a D$ & $\begin{array}{l}b b \\
b b\end{array}$ & $\begin{array}{l}a \\
b\end{array}$ & $\begin{array}{r}12 \mathrm{~m} \\
3 \mathrm{~m}\end{array}$ & $\begin{array}{l}8.5 \mathrm{~m} \\
8.5 \mathrm{~m}\end{array}$ & $17: 4$ \\
\hline & & & & & & & & $b b$ & $a b$ & $1 \mathrm{~m}$ & $\mathrm{NE}$ & \\
\hline & & & & & & & & $b f$ & $a$ & $1 \mathrm{~m}$ & $\mathrm{NE}$ & \\
\hline & & & & & & & & $b b$ & $a a$ & $2 \mathrm{f}$ & $2 f$ & \\
\hline & & & & & & & & $b b$ & $a b$ & $2 \mathrm{f}$ & $2 \mathrm{f}$ & \\
\hline \multirow{3}{*}{ LP } & SB & 9 & $b b$ & - & $x$ & be & - & $b b$ & - & 12 & 12.5 & $15: 10$ \\
\hline & & & & & & & & $b e$ & - & 11 & 12.5 & \\
\hline & & & & & & & & $e e$ & - & 2 & $\mathrm{NE}$ & \\
\hline \multirow{4}{*}{ LP } & SB & 10 & $b d$ & - & $x$ & $b d$ & - & $b b$ & - & 5 & 4.75 & $12: 7$ \\
\hline & & & & & & & & $b d$ & - & 9 & 9.5 & \\
\hline & & & & & & & & $d d$ & - & 4 & 4.75 & \\
\hline & & & & & & & & $d e$ & - & 1 & $\mathrm{NE}$ & \\
\hline \multirow{5}{*}{ LP } & SB & 11 & $b f$ & - & $x$ & $b e$ & - & $b b$ & - & 3 & 2.5 & $0: 10$ \\
\hline & & & & & & & & be & - & 5 & 2.5 & \\
\hline & & & & & & & & $b f$ & - & 0 & 2.5 & \\
\hline & & & & & & & & ef & - & 1 & 2.5 & \\
\hline & & & & & & & & $e e$ & - & 1 & $\mathrm{NE}$ & \\
\hline
\end{tabular}




\begin{tabular}{|c|c|c|c|c|c|c|c|c|c|c|c|c|}
\hline \multirow[b]{2}{*}{$\begin{array}{l}\text { Population } \\
\text { of origin }\end{array}$} & \multirow[b]{2}{*}{ Morph } & \multirow[b]{2}{*}{$\begin{array}{l}\text { Cross } \\
\text { number }\end{array}$} & \multicolumn{3}{|c|}{$\begin{array}{l}\text { Genotype of } \\
\text { male partner }\end{array}$} & \multicolumn{2}{|c|}{$\begin{array}{l}\text { Genotype of } \\
\text { female parent }\end{array}$} & \multicolumn{4}{|c|}{$\begin{array}{l}\text { Observed and expected } \\
\text { offspring genotypes }\end{array}$} & \multirow{2}{*}{$\begin{array}{l}\text { Number of } \\
\text { male:female } \\
\text { offspring }\end{array}$} \\
\hline & & & $\begin{array}{l}\text { Locus } \\
\text { Gpi }\end{array}$ & $\mathrm{Pgm}$ & & $\begin{array}{l}\text { Locus } \\
G p i\end{array}$ & $P g m$ & $\begin{array}{l}\text { Locus } \\
G p i\end{array}$ & $P g m$ & Obs. & Exp. & \\
\hline LP & SB & 12 & be & - & $\times$ & $b f$ & - & $\begin{array}{l}b b \\
b e \\
b f \\
e f\end{array}$ & $\begin{array}{l}- \\
- \\
-\end{array}$ & $\begin{array}{l}2 \\
0 \\
2 \\
0\end{array}$ & $\begin{array}{l}1 \\
1 \\
1 \\
1\end{array}$ & $3: 1$ \\
\hline LP & SB & 13 & ND & ND & $\times$ & $b e$ & - & $\begin{array}{l}b b \\
b e\end{array}$ & - & $\begin{array}{l}4 \\
5\end{array}$ & $\begin{array}{l}\text { NA } \\
\text { NA }\end{array}$ & $3: 6$ \\
\hline LP & SB & 14 & ND & ND & $x$ & $b b$ & - & $\begin{array}{l}b b \\
b d \\
b e\end{array}$ & $\begin{array}{l}- \\
-\end{array}$ & $\begin{array}{l}6 \\
2 \\
2\end{array}$ & $\begin{array}{l}\text { NA } \\
\text { NA } \\
\text { NA }\end{array}$ & $5: 5$ \\
\hline
\end{tabular}

*This female was placed with two males.

†This female was not placed with a male but had had exposure to males prior to being placed in isolation.

$¥$ This female was not reproductive when kept in isolation, she produced offspring only after she was later placed with two males. $\mathrm{ND}=$ the genotype of these individuals was not determined.

$\mathrm{NA}=$ the expected offspring genotype frequencies could not be calculated either because the genotype of the male partner was unknown or because the female had two partners.

$\mathrm{NE}=$ either the observed offspring genotype was not expected to result from a sexual cross between the female parent and her male partner or a male heterozygous for the Pgm locus was not expected.

two of the progeny of another female possessed a nonmaternal allele and, in this case, the different allele was carried by the male partner (Table 4 , cross 2 , the 'e' allele at the Pgm locus). The two females that did not produce diverse broods were homozygous at both marker loci and partnered with identical males, and so could not be expected to generate diverse broods (Table 4, crosses 3 and 4). In all cases where the genotypes of the male partner was known, the genotypes observed within broods could be accounted for by a sexual cross between the female parent and her male partner (Table 4, crosses 1-4).

The broods of swamp females always included at least one male and overall these broods comprised 17 males and 13 females (Table 4). This overall result is not significantly different from a sex ratio of $1: 1$ $\left(\chi^{2}=0.533\right.$; d.f. $\left.=1 ; P>0.2\right)$.

Small-brown morph. Sexual reproduction was typical of the small-brown females that were placed with males. Nine of 10 such females were sexually reproducing (this includes the once isolated female). The remaining one survived for a similar length of time, together with her male partner, but did not reproduce (Table 1).

Eight of the nine reproductive females were heterozygous for one locus and, without exception, they pro- duced genotypically diverse broods (Table 4). The sole homozygous female also produced a diverse brood (Table 4, cross 14). The broods of three females possessed paternally derived alleles (i.e. alleles present in the male but absent in his female partner) (Table 4, crosses 7, 11, and 12). Furthermore, the range (and sometimes even the frequency) of genotypes observed within a brood was usually consistent with expectations for a sexual cross between the female parent and her male partner (Table 4).

However, the genotype of one or two offspring in each of four broods could not be explained in terms of such a cross. This was because these offspring were homozygous for an allele that was represented only once among the putative parents or possessed an allele that was not present in either of the putative parents (Table 4, crosses 8, 9, 10 and 11). A likely explanation of this result is that the female parent had been fertilized prior to being placed in the jar (i.e. the 'novel' alleles were derived from an earlier mating). These females were probably also fertilized by their male partners as most of the offspring genotypes in their broods were consistent with the view that they were fathered by this male. Given that 'female 14' was a 'bb' homozygote at the Gpi locus, the genotypes of her offspring are also suggestive of multiple paternity (Table 4, cross 14). 
Overall the small-brown sexual females generated a total of 54 daughters and 63 sons (Table 4); a result which is not significantly different from a sex ratio of $1: 1\left(\chi^{2}=0.692 ;\right.$ d.f. $\left.=1 ; P>0.2\right)$. Some individuals, however, produced broods with a sex ratio deviating significantly from unity. One individual was particularly notable in this regard. She produced 10 daughters and no sons (Table 4, cross number 11). Nevertheless, the range of genotypes displayed by her daughters confirmed their sexual mode of production.

\section{Sex linkage}

The pattern of inheritance observed for the $\mathrm{Pgm}$ locus was in accordance with predictions that this is a sexlinked locus and the male is the heterogamous sex. For the large-green morph, for instance, a cross between a 'cc' female and an 'e' male resulted in 'ce' daughters and a 'c' son (Table 4, cross 2). In another instance, a female heterozygous at this locus produced some heterozygous daughters but no heterozygous sons (Table 4 , cross 5). Two small-brown females that were heterozygous at this locus also produced mostly homozygous sons (Table 4, crosses 6 and 8). However, one of these small-brown females, although producing 16 homozygous sons, also produced a heterozygous one (Table 4 , cross 8 ).

\section{Inheritance of morphological type.}

Both morphs always bred true, i.e. offspring always had the same morphological form as their parent(s). This was true despite the fact that all offspring were reared in virtually identical conditions and so indicates a heritable basis for the morphological differences.

\section{Discussion}

This study confirms the capacity of both morphs of $C$. novaezelandiae for sexual and parthenogenetic reproduction by showing that some females are able to produce genotypically uniform daughters by parthenogenesis and others are able to use sexual reproduction to generate genotypically diverse progeny of both sexes. Moreover, considerable variability in reproductive tactics is apparent within what may be a species or a species complex. Tactics include sexual reproduction with single or possibly multiple fertilizations and apomictic parthenogenesis, sometimes confirmed to separate populations or occurring within a single population. No exhaustive tests for facultative parthenogenesis were undertaken but available evidence suggests that the sexual and asexual forms both within and between morphs are independent.
This finding has important evolutionary implications as gene flow will be restricted to sexual forms of the same morph. Moreover, it suggests that parthenogenetic lineages have evolved within this group on at least two separate occasions. $C$. novaezelandiae is the second species of Ostracoda for which a mixed mode of reproduction has been confirmed [the other being Heterocypris incongruens (Bauer, 1940)] and it is the first for which such confirmation has been provided by breeding studies which allow for determination of the mode of inheritance of genetic markers.

Unisexual and mixed-sex populations (or species) of Ostracoda are generally assumed to reflect a reliance on alternative modes of reproduction (Hoff, 1942; Bell, 1982; Brohnstein, 1988). A few studies have provided genetic evidence in support of this view (Bauer, 1940; Tetart, 1975; Chaplin \& Ayre, 1989; Havel \& Hebert, 1989; Havel et al., 1990). The results of this study provide qualified support. The mode of reproduction of large-green females varied according to the presence or absence of males in their population of origin, except that some of the large-green parthenogens were from a population that included smallbrown, although not large-green, males. The mixed-sex population of the small-brown morph in Lake Purrumbete, however, appears to include both sexual and parthenogenetic females.

The taxonomic relationship between the large-green and small-brown morphological forms of $C$. novaezelandiae is not clear. Sars (1894) regarded them as sufficiently distinct to warrant species status and described the small-brown morph as $C$. assimilis and the largegreen one as $C$. candonioides $[=C$. novaezelandiae Eager (1971)]. De Deckker (1981) synonymized $C$. assimilis to $C$. novaezelandiae mostly on the basis that morphological differences between the two were restricted to differences in the size, shape and colour of the carapace and further proposed that the morphs represent different developmental stages of a single species. The small-brown form was said to be a precocious pre-adult stage. Given that the morphs bred true in the controlled laboratory environment of this study, however, it seems more likely that they are genetically independent. A breeding trial involving a cross between the sexual lineages of each morph would be useful in determining their potential for gene exchange but was not possible in this study. Whatever the case, gene flow between the two morphs is unlikely to occur in field situations since at least one of the morphs (and usually both) appears to be strictly parthenogenetic in the water bodies in which they co-exist (J. A. Chaplin personal observation).

There is also morphological variation within the two major forms of $C$. novaezelandiae. For the large-green 
morph, the most obvious differences occur between the sexual and asexual lineages. The sexuals, when compared to the asexuals, have a slightly more compressed carapace and the flange of the right valve is more prominent ( $\mathrm{P}$. De Deckker, personal communication). The adult sexuals also have relatively well developed swimming setae on the antennae and swim frequently. The adult asexuals rarely swim. These two lineages are also genetically distinctive at some loci (e.g. the ' $b$ ' allele which predominates at the $M p i$ locus in the sexuals is not found among the parthenogens). Given that the sexuals and parthenogens were collected from populations some $3,500 \mathrm{~km}$ apart, these morphological and genetic differences may reflect spatial patterns of variation within the large-green morph of $C$. novaezelandiae. Alternatively, these differences might be indicative of a more fundamental distinction between the two lineages. Differences within the smallbrown morph are more subtle and take the form of variation in the shape, size, and colour of the carapace. It is not known if any of this variation corresponds to differences in the mode of reproduction of smallbrown individuals.

The taxonomic status of $C$. novaezelandiae is further complicated by the fact that, in addition to the "two major but somewhat variable morphs', there are individuals with a morphology intermediate between the two extremes (J. A. Chaplin personal observation). Furthermore, two females from Lake Purrumbete, which were identified as large-green parthenogens in this study (the number 7 individuals in Tables 2 and 3), have multilocus genotypes closely aligned to those of clonal lineages of the small-brown morph from other water bodies (J. A. Chaplin personal observation). Clearly, more work is required to resolve the relationships among the complex assemblage of morphological and reproductive types within $C$. novaezelandiae.

There is marked variation in the structure of local populations of the large-green morph of $C$. novaezelandiae. Of 45 populations sampled in south-eastern Australia, all consisted of females only and were dominated by a few highly replicated genotypes (Chaplin \& Ayre, 1989; J. A. Chaplin personal observation). This contrasts markedly with the relatively genotypically diverse mixed-sex population resident in Cracker's Swamp in Western Australia (Chaplin \& Ayre, 1989). The results of this study reveal the proximate cause of this variation. Most populations in south-eastern Australia probably consist of females which produce genotypically uniform sets of daughters by parthenogenesis. On the other hand, individuals in the swamp population have the capacity for sexually generating genotypically diverse offspring of both sexes. Furthermore, these differences appear to reflect genetically based variation in the mode of reproduction. Clearly at least, the determinants of the mode of reproduction are more strongly associated with the source of females rather than the culture conditions per se. Females from the mixed-sex population did not reproduce without exposure to males and used sexual reproduction when males were available. In contrast, females from the two pond populations used parthenogenetic reproduction both in the presence and absence of large-green males. Brohnstein (1988; p.20) suggested that conspecific sexual and asexual forms of the Ostracoda represent 'different races with different genotypes'. Such a suggestion could account for these results with the source of females being a particular stock with a genetically fixed mode of reproduction.

There are unsubstantiated claims of facultative parthenogensis for some species of Ostracoda. Wohlgemuth (1914) (cited by Kesling, 1951) reported to have affected a change in the mode of reproduction of Heterocypris incongruens by maintaining 'sexual females' in the absence of males and 'parthenogenetic females' on a near-starvation diet. Bauer (1940) and others have, however, questioned Wohlgemuth's claims. McKenzie (1971) proposed that some Ostracoda normally use sexual reproduction in equatorial locations but switch to parthenogenetic reproduction at higher latitudes (relatively stressful environments) because the degree of environmental stress directly controls their mode of reproduction. However, the situation described by McKenzie could also be accounted for by sexual and parthenogenetic races with disjunct distributions.

Although facultative parthenogenesis seems unlikely for the large-green morph of $C$. novaezelandiae, such a possibility cannot be dismissed. It could be argued that the swamp females had been pre-conditioned for a sexual response prior to their being placed in the jar. The parthenogenetic females that were partnered in with large-green males, on the other hand, were of pond stock but laboratory-bred, and so were unlikely to have been influenced by the pond environment except perhaps via maternal contact. Nevertheless, the stimuli required to trigger a sexual response in these individuals may have been absent from the laboratory cultures. Experimental studies have shown that the transition from sexual to asexual reproduction in other organisms can be induced by a wide variety of sometimes complex treatments (Birky \& Gilbert, 1971; Bell, 1982; Carvalho \& Hughes, 1983). Often the stimuli involved are directly or indirectly related to high population densities (Bell, 1982; p. 370; Carvalho \& Hughes, 1983) but this, at least, seems unlikely to be relevant in this case since neither Sars (1889) nor I have observed any evidence of a sexual mode of repro- 
duction in crowded laboratory cultures of $C$. novaezelandiae [= Herpetocypris stanleyana of Sars, (De Deckker, 1981)].

On the basis of its bisexual nature, the small-brown morph was expected to be sexually reproducing in Lake Purrumbete but, in fact, it may include separate sexual and parthenogenetic lineages. This situation is contrary to that described for the large-green morph where, although the sexual and asexual forms are likely to be independent, they were collected from locations some $3,500 \mathrm{~km}$ apart. Certainly, most of the smallbrown females tested either used sexual reproduction when partnered with males or did not reproduce in isolation. Nevertheless, one virginal female reproduced by parthenogenesis. Furthermore, the parthenogenetic female, when compared to the sexual ones, possessed a distinctive genotype at the $M p i$ locus (she was characterized by a relatively mobile enzyme variant of MPI). This suggests that there may be a genetic basis for the observed variation in the mode of reproduction among small-brown individuals. The fact that six other unmated small-brown females did not reproduce by parthenogenesis provides a further indication that the observed variation is independent of the culture conditions. Finally, a significant female-bias in the sex ratio of samples of the small-brown morph from Lake Purrumbete (e.g. in the sample used for these breeding trials the female to male ratio was 5.5:1, $n=325$ ) suggests that this population may include a significant number of parthenogenetic females.

Female-biased sex ratios are common among dioecious species of Ostracoda (McKenzie, 1971; Tetart, 1975; Bell, 1982; Harten, 1983; Havel et al., 1990) and are usually explained in terms of reduced longevity and sometimes reduced vitality of males (McKenzie, 1971; Tetart, 1975; Bell, 1982; Harten, 1983). Alternatively, Havel et al. (1990) have proposed that such a bias may be related to the unusual sex determining mechanism of many ostracod species which involves multiple $\mathrm{X}$ chromosomes (e.g. $\mathrm{X}_{\mathrm{n}} \mathrm{Y}$ or $\mathrm{X}_{\mathrm{n}} \mathrm{O}$ mechanisms). Such a mechanism could result in a male sharing more genes with his daughters than with his sons and so may favour the spread of any genes which bias the sex ratio of a male's progeny in favour of females. The broods of some small-brown individuals did have a sex ratio that deviated markedly from unity but femaledominated broods were not produced any more often than male-dominated ones. Furthermore, no sexrelated differences in survivorship or longevity in the laboratory cultures were noticed for $C$. novaezelandiae (although controlled experiments designed to detect such differences were not performed). Thus more usual explanations of the preponderance of females in this taxa seem less likely to account for an excess of small- brown females in Lake Purrumbete than does the proposed mix of sexual and parthenogenetic females. In Cracker's Swamp, the large-green morph appears to include a similar proportion of males and females [the female to male ratio in the sample used for these breeding experiments was 1.22:1 $(n=235)]$.

If one accepts that the extent of the excess of smallbrown females in Lake Purrumbete reflects the relative abundance of parthenogenetic individuals in this population, then it appears that the asexual lineage is displacing the sexual one. Samples collected from this water body over the past two years indicate that the relative number of small-brown females is increasing with time. The female to male ratio was $2.76: 1(n=207)$ in a sample collected in December 1988; 3.35:1 $(n=743)$ in April $1989 ; 4.76: 1(n=173)$ in July $1989 ; 5.5: 1$ $(n=325)$ in February 1990 and had increased to 6.9:1 $(n=307)$ by March 1991 (J. A. Chaplin personal observation). Furthermore, in a sample taken from this population about 20 years ago there were approximately equal numbers of males and females $(n=1,000)$ (Hussainy, 1969). Large-green asexuals also occur in Lake Purrumbete but the small-brown morph predominates (about 90 per cent of individuals are of the small-brown type) (J. A. Chaplin personal observation). The small-brown morph was the only one dectected in the sample of some 1,000 individuals collected about 20 years ago by Hussainy. Thus, the large-green morph may be a relatively recent arrival in this water body and this may explain its relatively low frequency. The Lake Purrumbete population is interesting in that it includes a diversity of types: large-green asexuals as well as small-brown sexuals and presumably asexuals. This diversity appears to derive from the coexistence of three genetically distinct groups the relative abundance of which may be changing through time.

Sex-linked characters are apparently rare in the Crustacea. In a review article Ginsburger-Vogel \& Charniaux-Cotton (1982), while acknowledging the paucity of relevant studies, reported only three known cases. Recent work, however, suggests that the Ostracoda may be exceptional among the Crustacea in that it is characterized by an unusually high frequency of sexlinked genes (Havel et al., 1990). This apparent extensive sex-linkage may be a consequence of the $\mathrm{X}_{\mathrm{n}} \mathrm{Y}$ or $\mathrm{X}_{\mathrm{n}} \mathrm{O}$ sex determining mechanisms employed by many ostracod species which may allow for a significant portion of the genome to be sex-linked (Havel et al., 1990). Variation at the Pgm locus in the small-brown and large-green morphs of $C$. novaezelandiae was consistent with exceptations for sex-linkage. Only two loci were found to be variable in the sexual populations of C. novaezelandiae and evidence of sex-linkage was 
obtained for one of them. This finding is consistent with claims of extensive sex-linkage in this group. The one heterozygous small-brown male that was detected could be explained by non-disjunction of some of the sex chromosomes during meiosis (White, 1973; Havel et al., 1990).

Apomixis is a common cytological mechanism of parthenogenesis (White, 1973; Bell, 1982). This is the mechanism used by the few asexual Ostracoda that have been appropriately studied (Bauer, 1940; Tetart, 1975; Havel \& Hebert, 1989; Rossi \& Menozzi, 1990). The same seems to be true of $C$. novaezelandiae as the broods of all but one of the heterozygous parthenogenetic females lacked genotypic variation. The limited variation detected within the one exceptional brood was probably due to either mutation or crossing-over during a single maturation division (essentially somatic crossing over). The occurrence of this variation is in itself interesting as it attests to the potential of $C$. novaezelandiae clones to accumulate genetic variation that is independent of any sexual or psuedo-sexual process. Mutational divergence of clones has been reported for a variety of clonal organisms (Suomalainen et al., 1976; Whitham \& Slobodchikoff, 1981; Stoddart, 1983a; Hughes, 1989). Such divergence can be of adaptive significance (Whitman \& Slobodchikoff, 1981; Hughes, 1989).

\section{Acknowledgements}

I am grateful to David Ayre for his advice throughout this study and especially for his help with the manuscript. I am also grateful to Patrick De Deckker for his help regarding the taxonomy of Candonocypris novaezelandiae. I thank Stuart Halse and Alison Ruby Hunt for collecting samples from Cracker's Swamp, and Andy Davis, Alison Hunt, Sue Schibeci and Rob Whelan for useful comments on the manuscript. I gratefully acknowledge the financial support provided by the University of Wollongong and the MurrayDarling Freshwater Research Centre.

\section{References}

BAUER, H. 1940. Über die Chromosonen der bisexuellen und der parthenogenetischen Rasse des Ostracoden Heterocypris incongruens Ramd. Chromosona, 1, 620-637.

BELL, G. 1982. The Masterpiece of Nature: the Evolution and Genetics of Sexuality. Croom Helm, London.

BIRKY, C. W. AND GILBERT, J. J. 1971. Parthenogenesis in rotifers: the control of sexual and asexual reproduction. Am. Zool., 11, 245-266.

BRoHnSTEIN, z. S. 1988. Fresh-Water Ostracoda. Academy of Sciences of the USSR. Moscow.
CABlE, R. M. 1971. Parthenogenesis in parasitic helminths. Am. Zool., 11, 267-272.

CARVAlHO, G. R. AND HUGHES, R. N. 1983. The effect of food availability, female culture-density and photoperiod on ephippia production in Daphnia magna Straus (Crustacea: Cladocera). Freshwater Biol., 13, 37-46.

CHAPLIN, J. A. AND AYRE, D. J. 1989. Genetic evidence of variation in the contributions of sexual and asexual reproduction to populations of the freshwater ostracod Candonocypris novaezelandiae. Freshwater Biol., 22 , 275-284.

DE DECKKER, P. 1981. Ostracoda from Australian inland waters: notes on taxonomy and ecology. Proc. R. Soc. Vict., 93, 45-83.

DE DECKKER, P. 1983. Notes on the ecology and distribution of non-marine ostracods in Australia. Hydrobiologia, 106, 223-234.

DE DECKKER, P. AND WiLliams, w. D. 1988. Physiochemical limnology of eleven, mostly saline permanent lakes in western Victoria, Australia. Hydrobiologia, 162, 275-286.

EAGER, S. H. 1971. A checklist of Ostracoda of New Zealand. J. R. Soc. NZ., 1, 53-64.

GINSBURGer-VOGEL, T. AND CharniauX-COTTON, H. 1982. Sex determination. In: Abele, L. G. (ed.) The Biology of Crustacea, Academic Press, London, pp. 257-281.

GROSBERG, R. K, 1988. Life-history variation within a population of the colonial ascidian Botryllus schlosseri. 1. The genetic and environmental control of seasonal variation. Evolution, 42, 900-920.

HARSHMAN, L. G. AND FUTUYMA, D. J. 1985. The origin and distribution of clonal diversity in Alsophila pometaria (Lepidoptera: Geometridae). Evolution, 39, 315-324.

HARTEN, D. VAN. 1983. Resource competition as a possible cause of sex ratio in benthic ostracods. In: Maddocks, R. F. (ed.) Applications of Ostracoda, University of Houston Geosciences, Houston, pp. 568-580.

HAVEL, J. E. AND HEBERT, P. D, N, 1989. Apomictic parthenogenesis and genotypic diversity in Cypridopsis vidua (Ostracoda: Cyprididae). Heredity, 62, 383-392.

HAVEL, J. E., HEBERT, P. D. N. AND DELORME, L. D. 1990. Genetics of sexual Ostracoda from a low Arctic site. J. Evol. Biol., 3, 65-84.

HEBERT, P. D. N. AND CREASE, T. 1983. Clonal diversity in populations of Daphnia pulex reproducing by obligate parthenogenesis. Heredity, 51, 353-369.

HOFF, C. C. 1942 . The ostracods of Illinois, their biology and taxonomy, Il. Biol. Monogr., 19, 1-196.

Hussainy, s. U. 1969. Description of the male of Candonocypris assimilis G. O. Sars 1894 (Cypridae, Ostracoda). Proc. R. Soc. Vict., 82, 305-307.

Hughes, R. N. 1989. A Functional Biology of Clonal Animals. Chapman and Hall. London.

KESLING, R. V. 1951. The morphology of ostracod moult stages Il. Biol. Monogr., 21, 1-324.

MCKENZIE, K. G. 1971. Palaeozoogeography of freshwater Ostracoda. In: Oertli, H. J. (ed.) Paléoécologie des Ostracodes. Bull. Centre Rech. Pau-SNPA, 5 Suppl., 207-237.

PENNACK, R. w. 1953. Fresh-Water Invertebrates of the United States. Ronald Press. New York. 
RICHARDSON, B. J., BAVERSTOCK, P. R. AND ADAMS, M. 1986. Allozyme Electrophoresis. Academic Press. Sydney.

Rossi, v. AND MENOzzI, M. 1990. The clonal ecology of Heterocypris incongruens (Ostracoda). Oikos, 388-398.

SARS, G. o. 1889. On some freshwater Ostracoda and Copepoda raised from dried Australian mud. Forh. VidenskSelsk. Krist., 8, 1-79.

SARS, G. O. 1894. Contributions to the knowledge of the freshwater Entomostraca of New Zealand as shown by artificial hatching from dried mud. Forh. Vidensk-Selsk. Krist., 5, $1-62$.

STODDART, J. A. 1983a. The accumulation of genetic variation in a parthenogenetic snail. Evolution, 37, 546-554.

STODDART, J. A. $1983 \mathrm{~b}$. Asexual production of planulae in the coral Pocillopora damicornis. Mar. Biol., 76, 279-284.

SUOMALAINEN, E., SAURA, A. AND LOKKI, J. 1976. Evolution of parthenogenetic insects. Evol. Biol., 9, 209-257.

TETART, J. 1975. Recherches sur la reproduction et l' ecologie de quelques Ostracodes Cyprididae. Ph.D. Thesis, USM Grenoble.

white, M. J. D. 1973. Animal Cytology and Evolution. Cambridge University Press, London.

WHITHAM, T. G. AND SLOBODCHIKOFF, C. N. 1981. Evolution by individuals, plant-herbivore interactions, and mosaics of genetic variability: the adaptive significance of somatic mutations in plants. Oecologia, 49, 287-292.

WILSON, F. AND woolCocK, L. T. 1960. Temperature determination of sex in a parthenogenetic parasite, Ooencyrtus submetallicus (Howard) (Hymenoptera: Encyrtidae). Aust. J. Zool., 8, 153-169.

WOHLGEMUTH, R. 1914. Beobachtungen und Untersuchungen über die Biologie der Süsswasserostracoden; ihr Vorkommen in Sachsen und Böhmen, ihre Lebensweise und ihre Fortpflanzung. Int. Rev. Hybrobiol., Biol. Suppl., 6, $1-72$. 